\title{
EKSTRUKSI DAN KARAKTERISASI FILAMEN KOMPOSIT POLYLACTID ACID (PLA) / CARBON NANO TUBE (CNT)
}

\author{
Dicky Oktavian \\ Program Studi Magister Teknik Mesin \\ Departemen Teknik Mesin dan Industri, \\ Fakultas Teknik, Universitas Gadjah Mada \\ Yogyakarta 55281, Indonesia \\ dicky.oktav@ugm.ac.id
}

\author{
Muslim Mahardika \\ Departemen Teknik Mesin dan Industri, \\ Fakultas Teknik, Universitas Gadjah Mada \\ Yogyakarta 55281, Indonesia, \\ Centre for Innovation of Medical Equipment and \\ Devices (CIMEDs), Fakultas Teknik, \\ Universitas Gadjah Mada \\ muslim_mahardika@ugm.ac.id
}

\author{
Budi Arifvianto \\ Departemen Teknik Mesin dan Industri, \\ Fakultas Teknik, Universitas Gadjah Mada \\ Yogyakarta 55281, Indonesia \\ Centre for Innovation of Medical Equipment and \\ Devices (CIMEDs), Fakultas Teknik, Universitas Gadjah Mada \\ budi.arif@ugm.ac.id
}

\begin{abstract}
ABSTRAK
Dewasa ini teknologi additive manufacturing (AM) mengalami perkembangan yang pesat. Salah satu metode additive manufacturing yang saat ini populer di berbagai belahan dunia adalah metode fused deposition modelling. Prinsip kerja metode ini adalah dengan cara mengekstrusi material filamen polimer yang meleleh dan sudah melewati temperatur rekristalisasinya melalui sebuah nozzle, kemudian produk akan terbentuk secara lapis demi lapis yang dibentuk melalui gerakan relatif dari meja mesin. Dalam pengaplikasiannya, material filamen dapat dibuat dalam bentuk komposit sehingga diperoleh sifat-sifat unik tertentu sehingga dapat digunakan pada bidang-bidang tertentu. Salah satunya adalah pada bidang kesehatan, sebagai pembuatan implan atau jaringan tubuh dengan memiliki kekuatan yang tinggi dan bersifat biodegradable. Pada penelitian ini, dilakukan pembuatan filamen komposit PLA-CNT dengan metode ekstrusi. Proses ekstrusi dilakukan dengan variasi temperatur 143, 145 , dan $147^{\circ} \mathrm{C}$ dengan memberi tambahan polyethylene glycol (PEG) sebagai plasticizer untuk meningkatkan fleksibilitas dan workability. Hasil pengamatan dengan scanning electron microscope (SEM) mengindikasikan bahwa proses ekstrusi berjalan kurang stabil karena terdapat tekstur permukaan yang bergelombang. Dari pengujian karakterisasi differential scanning calorimetry (DSC), derajat kristalinitas pada variasi ekstrusi filamen PLA-CNT mengalami peningkatan seiring meningkatnya temperatur ekstrusi. Pada pengujian karakterisasi Fourier Transform Infrared Spectroscopy (FTIR) terdapat perubahan komposisi kimia pada filamen yang signifikan, yang juga sejalan dengan degradasi sifat mekanis. Variasi filamen dengan temperatur ekstrusi $147^{\circ} \mathrm{C}$ memiliki nilai kekerasan paling tinggi yaitu sebesar 40,5 $\mathrm{MPa}$.

Kata kunci: PLA, filamen, carbon nano tube, ekstrusi, polyethylene glycol
\end{abstract}

\section{PENDAHULUAN}

Teknologi additive manufacturing mengalami perkembangan yang sangat cepat dan signifikan di berbagai belahan dunia. Additive manufacturing adalah merupakan proses fabrikasi ekstrusi dan deposisi material lapis demi lapis guna menciptakan obyek 3D dari struktur 3D gambar Computer Aided Design (CAD) [1]. Pada penggunaannya di kehidupan sehari-hari teknologi ini biasa disebut dengan $3 \mathrm{D}$ printing.

Metode yang populer digunakan pada 3D printing adalah metode fused deposition modeling. Metode ini bekerja dengan cara mengekstrusi material filamen yang telah meleleh melewati temperatur rekristalisasinya melalui sebuah nozzle, kemudian produk akan terbentuk secara lapis demi lapis yang dibentuk melalui gerakan relatif dari meja mesin. Metode FDM begitu populer digunakan karena metode ini mudah untuk digunakan, biaya operasional rendah dan ramah lingkungan untuk produk-produk prototyping sebagai proses manufaktur dalam aplikasi industri [2]. Selain itu, teknologi ini memungkinkan benda kerja dengan geometri rumit dapat diproduksi dengan mudah dan cepat. Salah satu bentuk pengaplikasian adalah pada bidang kesehatan, pembuatan implan biomedis melalui teknik FDM menarik perhatian berbagai peneliti, metode produksi ini menawarkan pembuatan implan atau jaringan tubuh dapat dibuat menyerupai bentuk organ tubuh alami atau spesifik dari pasien berdasarkan pada hasil pemindaian Computed Tomography Scanner (CT-Scan) [3]. Untuk mencapai hal tersebut dibutuhkan alternatif material biomedis yang dapat di proses dengan teknik FDM, dimana material tersebut bersifat biodegradable, non-toxic, dan memiliki mechanical properties yang memenuhi standar biomedis.

Material untuk proses 3D printing disebut juga dengan sebutan filamen. Filamen yang paling sering digunakan adalah polylactic acid (PLA), acrylonitrile butadiene styrene (ABS), polyvinyl alcohol (PVA), dan 
polyamide (Nylon). Dari beberapa pilihan material tersebut, yaitu PLA mempunyai sifat mekanik dan kimia yang baik, serta merupakan material yang ramah terhadap lingkungan, bersifat biodegradable, dan non- toxic. Secara umum, meskipun material PLA murni memiliki beberapa keunggulan, PLA murni masih memiliki kekurangan yaitu kekuatan, stabilitas termal, dan elektrikal yang rendah. Hal tersebut menjadi pengaplikasian PLA sangat terbatas. Untuk meningkatkan mechanical properties PLA murni dibutuhkan teknik rekayasa. Teknik rekayasa yang digunakan yaitu dengan pembuatan komposit PLA diperkuat dengan berbagai bahan tambahan (additive), seperti serat alami kayu, serat karbon, serbuk bio-karbon, serbuk logam, hydroxyapatite, dan serbuk keramik [4]. Salah satu bahan yang dapatmemperkuat PLA adalah Carbon Nano Tube (CNT).

Carbon Nano Tube adalah senyawa karbon yang berukuran nanometer. Material ini memiliki sifat fisis dan mekanik yang tidak biasa, diantaranya adalah memiliki stabilitas termal dan listrik yang baik, serta memiliki kekuatan yang tinggi melebihi kekuatan dari baja carbon. Dari sifat yang dimiliki tersebut, CNT dapat diaplikasikan menjadi struktur penguat bagi polimer PLA. Berdasarkan beberapa penelitian yang sudah dilakukan, penambahan CNT pada PLA dapat menunjukkan peningkatkan material properties, stabilitas termal, dan elektrikal yang baik.

Ditinjau dari sifat-sifat material dari kedua bahan tersebut, pada penilitian ini dilakukan pembuatan filamen komposit PLA/CNT sebagai bahan baku 3D printing FDM. Proses pembuatan filamen dilakukan dengan mesin ekstrusi single screw. Dari hasil studi literatur, hingga saat ini masih sedikit informasi mengenai sifat fisis dan mekanis filamen komposit PLA/CNT dari hasil proses ekstrusi. Pada penelitian ini akan diteliti mengenai sifat fisis dan mekanis komposit PLA/CNT sehingga nantinya dapat diaplikasikan sebagai filamen bahan baku pada teknologi 3D printing FDM. Untuk mendapatkan hasil yang terukur dilakukan karakterisasi dari filamen komposit PLA/CNT dengan cara melakukan pengujian material. Analisa dilakukan dengan cara membandingkan data kuantitatif dari hasil pengujian filamen komposit PLA/CNT dengan filamen PLA murni untuk melihat tingkat keberhasilan dari penelitian.

Penelitian ini bertujuan untuk mengetahui pengaruh penambahan carbon nano tube terhadap sifat fisis dan mekanis material PLA dengan metode ekstrusi serta menghasilkan komposit filamen PLA/CNT dengan sifat fisis dan mekanis yang dapat diaplikasikan sebagai filamen bahan baku 3D printing FDM. Hasil identifikasi tersebut kemudian digunakan untuk memberikan informasi tentang karakteristik filamen komposit PLA/CNT sehingga mampu menghasilkan sebuah kombinasi parameter optimal ekstruksi filamen yang dapat menjadi acuan untuk pembuatan material 3D printing.

\section{MATERIAL DAN METODE PENELITIAN}

Bahan utama yang digunakan pada penelitian ini adalah Granular PLA (2002d, NatureWorks - Amerika) dengan diameter $\pm 3 \mathrm{~mm}$, Serbuk Carbon Nano Tube
(CNT) single wall dengan diameter $10 \mathrm{~nm}$ dan panjang 8$10 \mu \mathrm{m}$, serta Zat tambahan berupa polyethylene glycol (PEG) sebagai plasticizer.

Pada tahap awal untuk menentukan temperatur ekstrusi dilakukan proses karakterisasi material PLA dengan pengujian Differential Scanning Calorimetry (DSC) pada mesin DSC-60 Plus (Shimadzu, Jepang), menggunakan gas nitrogen dengan laju pemanasan $10^{\circ} \mathrm{C} /$ menit. Pengujian awal juga dilakukan uji Fourier Transform Infrared Spectroscopy (FTIR) terhadap PLA untuk mengetahui unsur-unsur dan ikatan kimia molekul yang menyusun. Pengujian Scanning Electron Microscope (SEM) dilakukan terhadap CNT untuk menentukan tipe dari CNT yang digunakan.

Proses pencampuran granular PLA, serbuk CNT, dan zat additive PEG dilakukan menggunakan planetary ball mill dengan kecepatan putar pencampuran sebesar 500 rpm selama 30 menit. Planetary ball mill digunakan agar mendapatkan campuran yang homogen. Variasi campuran yang digunakan pada penelitian ini adalah PLA dengan massa 50 gram, PLA 0,025 wt\%, dan PEG 3 wt $\%$.

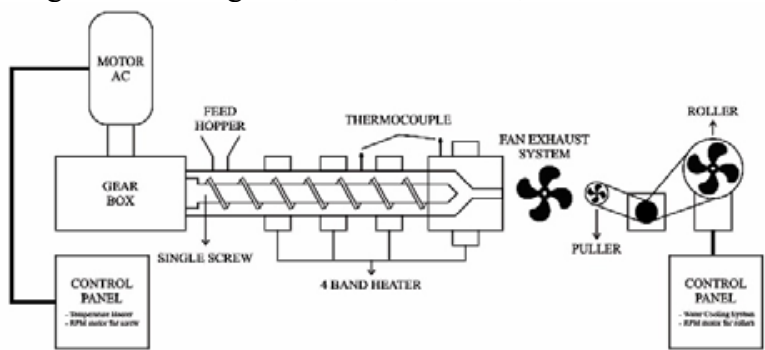

Gambar 1. Sketsa Mesin Single Screw Extruder.

Proses ekstrusi dilakukan dengan menggunakan single screw extruder. Extruder dilengkapi dengan empat band heater dengan rincian tiga heater digunakan sebagai pre-heat dan satu heater digunakan pada nozzle berdiameter $1.75 \mathrm{~mm}$ untuk menjaga temperatur ekstrusi seperti yang terlihat pada Gambar 1. Temperatur ekstrusi yang digunakan pada penelitian ini adalah 143, 145, dan $147^{\circ} \mathrm{C}$, seperti yang tertera pada tabel variasi ekstrusi filamen PLA-CNT (Tabel 1).

Tabel 1. Variasi ekstrusi filamen PLA-CNT

\begin{tabular}{c|c|c|c|c}
\hline \multirow{2}{*}{$\begin{array}{c}\text { PLA } \\
(\text { gram })\end{array}$} & $\begin{array}{c}\text { CNT } \\
(\mathrm{wt} \%)\end{array}$ & $\begin{array}{c}\text { PEG } \\
\left(\mathrm{wt}^{\%} \%\right)\end{array}$ & $\begin{array}{c}\text { Temp. } \\
\text { Ekstrusi } \\
\left({ }^{\circ} \mathrm{C}\right)\end{array}$ & $\begin{array}{c}\text { Kode } \\
\text { Spesimen }\end{array}$ \\
\hline \multirow{3}{*}{50} & 0 & 0 & 143 & Murni \\
\cline { 2 - 5 } & \multirow{2}{*}{0,050} & \multirow{2}{*}{5} & 143 & $\mathrm{C} 50$ P5 T143 \\
\cline { 4 - 5 } & & & 145 & $\mathrm{C} 50$ P5 T145 \\
\cline { 4 - 5 } & & & 147 & $\mathrm{C} 50$ P5 T147 \\
\hline
\end{tabular}

Semua filamen hasil ekstrusi di karakterisasi dengan menggunakan pengujian DSC dan FTIR untuk melihat sifat-sifat fisik dan kimiawi. Pada Pengujian DSC, akan didadapatkan data derajat kristalinitas filamen $(\% \mathrm{X})$, dengan persamaan (1):

$$
\% X=\frac{\Delta H_{\text {endotherm }}}{\Delta H_{f}} \times 100 \%
$$

dengan,

$\Delta H_{\text {endotherm }}:$ Kalor endotermik $(\mathrm{J} / \mathrm{g})$

$\Delta H_{f} \quad:$ Kalor fusi PLA murni $(93 \mathrm{~J} / \mathrm{g})$ 
Untuk mengetahui sifat mekanis pada filamen hasil ekstrusi dilakukan pengujian kekerasan metode vickers menggunakan alat uji kekerasan HMV-M3(Shimadzu, Jepang) dengan beban indentasi sebesar 200 gf dan waktu indentansi selama 5 detik. Nilai Vickers microhardness ditentukan dengan persamaan (4):

$$
\begin{aligned}
& d=\frac{d_{1}+d_{2}}{2} \\
& H V=\frac{F d^{2}}{2 \sin (12) \alpha} \\
& H V=1,8544 \frac{F}{d^{2}}
\end{aligned}
$$

dengan,

$$
\begin{array}{cl}
\mathrm{HV} & : \text { Angka kekerasan, }\left(\mathrm{kg} / \mathrm{mm}^{2}\right) \\
\mathrm{F} & : \text { Beban penekanan, }(\mathrm{kg}) \\
\mathrm{d} & : \text { Diagonal rata-rata indentansi }(\mathrm{mm})
\end{array}
$$

Morfologi filamen dari hasil ekstrusi juga diamati dengan pengujian SEM menggunakan alat Phenom Desktop ProXL (Thermo Fisher Scientific, Amerika).

\section{HASIL DAN PEMBAHASAN}

\section{Morfologi filamen PLA-CNT}

Pada penelitian ini, varian filamen PLA-CNT telah berhasil dibuat menggunakan single screw extruder. Morfologi dari filamen diamati dengan pengujian SEM dengan hasil seperti yang terlihat pada Gambar 2.
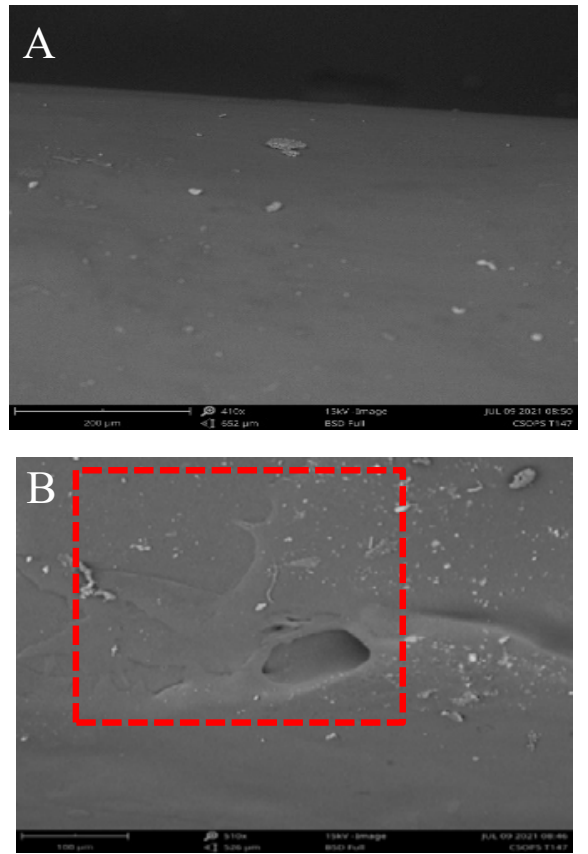

Gambar 2. (A) Morfologi permukaan filamen PLA-CNT dan (B) perbesarannya.

Hasil dari ekstrusi filamen menunjukkan permukaan filamen memiliki permukaan yang cenderung tidak bergelombang (Gambar 2.A). Pada sisi lain dengan pengamatan perbesaran lebih besar, morfologi filamen terlihat memiliki tekstur yang bergelombang yang ditandai dengan adanya guratan-guratan, serta lubang seperti yang tampak pada Gambar 2.B. Tekstur yang bergelombang mengindikasikan bahwa proses ekstrusi terjadi dengan feeding dan tekanan yang kurang stabil. Sedangkan lubang yang terdapat pada permukaan filamen terjadi karena udara yang terjebak yang mengakibatkan terjadinya porositas pada filamen. Semakin banyak porositas pada filamen akan berakibat menurunkan kekuatan tarik dari filamen [5].

\section{Hasil Karakterisasi Pengujian DSC}

Pengujian karakterisasi dengan DSC dilakukan untuk mengetahui pengaruh dari CNT terhadap PLA. Hal ini merujuk pada data peak melting temperature dan heat endhoterm yang dihasilkan sehingga dengan menggunakan persamaan (1) diketahui derajat kristalinitas seperti yang terlihat pada data Tabel 2 yang diharapkan dapat mempengaruhi sifat mekanis dari variasi PLA-CNT. Pada Gambar 3 menunjukkan grafik yang didapatkan dari pengujian DSC pada PLA murni 2002D dan variasi ekstrusi filamen PLA-CNT.

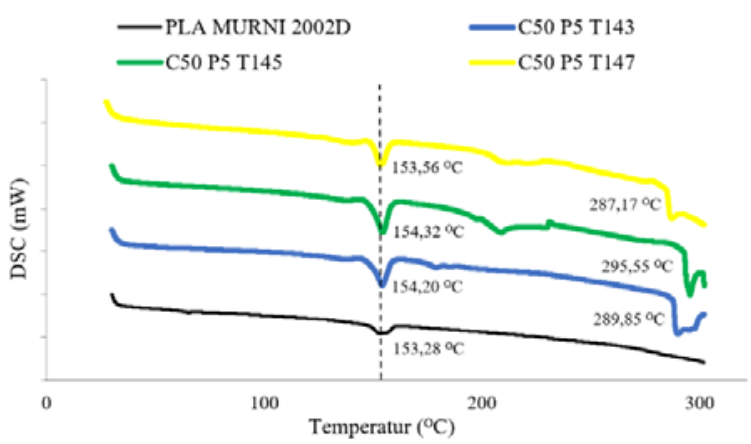

Gambar 3. Hasil pengujian DSC PLA 2002D dan variasi filamen PLA-CNT.

Data menunjukkan semua spesimen memiliki peak point yang berbeda-beda, tapi memiliki kesamaan yaitu memiliki nilai yang lebih tinggi daripada PLA Murni 2002D dengan nilai paling tinggi adalah spesimen C50 P5 $\mathrm{T} 145$ yaitu sebesar $154,32^{\circ} \mathrm{C}$ dengan heat endhoterm sebesar 29,83 J/g. Data tersebut membuktikan pengaruh dari CNT yang tersebar secara merata mengakibatkan PLA memiliki konduktivitas thermal yang lebih tinggi dari PLA Murni seiring dengan meningkatnya temperatur rekristalisasi [6].

Tabel 2. Hasil Pengujian DSC

\begin{tabular}{l|l|l|l}
\hline $\begin{array}{l}\text { Kode } \\
\text { Spesimen }\end{array}$ & $\begin{array}{l}\text { Temperatur } \\
\text { Melting }\left({ }^{\circ} \mathrm{C}\right)\end{array}$ & $\begin{array}{l}\text { Heat } \\
\text { endotherm } \\
(\mathrm{J} / \mathrm{g})\end{array}$ & $\begin{array}{l}\text { Derajat } \\
\text { kristalinitas } \\
(\%)\end{array}$ \\
\hline Murni & 153,28 & 25,93 & 27,88 \\
\hline C50 P5 T143 & 154,20 & 28,97 & 31,15 \\
\hline C50 P5 T145 & 154,32 & 29,83 & 32,08 \\
\hline C50 P5 T147 & 153,56 & 20,66 & 22,22 \\
\hline
\end{tabular}




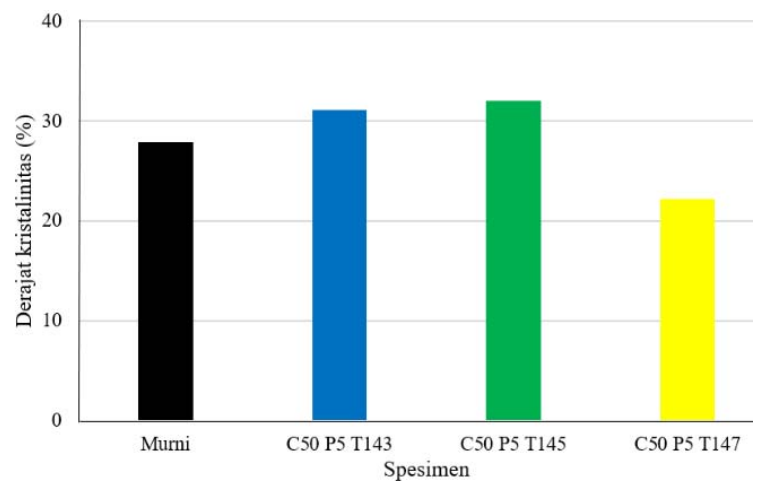

Gambar 4. Derajat kristalinitas PLA 2002D dan variasi filamen PLA-CNT.

Pada data yang ditunjukkan pada Tabel 2 dan di perjelas dengan Gambar 4. Derajat kristalinitas pada variasi ekstrusi filamen PLA-CNT mengalami peningkatan seiring meningkatnya temperatur ekstrusi dengan nilai derajat kristalinitas paling tinggi sebesar $32,08 \%$ pada temperatur ekstrusi $145^{\circ} \mathrm{C}$. Data tersebut menunjukkan CNT sebagai nucleating agent dan PEG untuk pengingkatan fleksibilitas mengakibatkan PLA mengalami peningkatan kekuatan ikatan antar molekul penyusun filamen. Hal ini dikarenakan pada fase kristalin kekuatan ikatan antar molekul jauh lebih tinggi bila dibandingkan dengan ikatan fase amorf [7].

Pada temperatur ekstrusi $147^{\circ} \mathrm{C}$, memiliki peak point serta derajat kristalinitas yang cenderung lebih rendah jika dibandingkan dengan varian temperatur ekstrusi yang lain. Pada temperatur ini peak point berada pada $153,56^{\circ} \mathrm{C}$, masih lebih tinggi daripada PLA murni, tapi lebih rendah dari varian temperatur ekstrusi yang lain. Hal ini terjadi karena pada temperatur ini PLA sudah melewati batas daripada glass transition temperature $\left(\mathrm{T}_{\mathrm{g}}\right)$, sehingga ikatan kristal yang terbentuk mengalami penurunan.

\section{Hasil Karakterisasi Pengujian FTIR}

Pengujian karakterisasi dengan FTIR dilakukan untuk mengetahui reaksi antar senyawa pada filamen komposit PLA-CNT-PEG dengan menganalisa puncakpuncak gelombang hasil pengujian. Pada Gambar 5 menunjukkan perbandingan hasil dari pengujian FTIR PLA 2002D murni dengan filamen PLA-CNT-PEG.

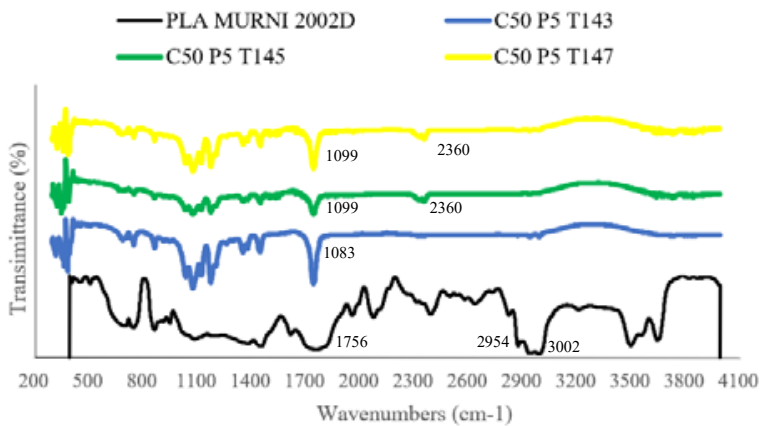

Gambar 5. Hasil Pengujian FTIR PLA 2002D dan Variasi Filamen
Pada grafik yang dihasilkan, jejak FTIR dari PLA teridentifikasi pada puncak gelombang 1756, 2954, dan $3002 \mathrm{~cm}^{-1}$ [8]. Pada rentang panjang gelombang 1000$1600 \mathrm{~cm}^{-1}$ menunjukkan adanya gugus fungsi $\mathrm{C}-\mathrm{C}$ dan $\mathrm{C}=\mathrm{C}$ yang merupakan jejak daripada penumbuhan $\mathrm{CNT}$ [9]. Senyawa PEG terditeksi pada puncak gelombang $1083,1099,2360 \mathrm{~cm}^{-1}$ [10]. Secara keseluruhan data yang dihasilkan pada filamen PLA-CNT-PEG menunjukkan terdapat pergeseran dan penambahan intensitas gelombang, hal tersebut menunjukkan sifat pencampuran yang baik dan mengindikasikan bertambahnya ikatan pada senyawa $[11,12]$.

Seperti yang terlihat pada grafik Gambar 4, filamen PLA-CNT-PEG memiliki perubahan intensitas gelombang. Pada rentang gelombang 1500-1600 $\mathrm{cm}^{-1}$ intensitas gelombang pada filamen PLA-CNT-PEG memiliki ikatan $\mathrm{C}=\mathrm{C}$ yang lebih sedikit bila dibandingkan dengan PLA Murni. Hal ini ditandai dengan intensitas gelombang pada rentang tersebut cenderung menurun, sehingga mengakibatkan menurunnya kekuatan ikatan antar senyawa pada material penyusun filamen.

\section{Hasil Pengujian Kekerasan}

Pengujian kekerasan dengan metode Vickers dilakukan untuk mengetahui sifat mekanis dari filamen. Kekerasan polimer diperlukan untuk mengethaui kekuatan kohesif dari rantai polymer [13]. Pada penelitian ini, uji microhardness dengan metode Vickers merupakan hal baru, karena kurangnya penelitian dalam literatur menganalisis kekerasan filamen termoplastik untuk aplikasi 3D [14]. Pada Gambar 5 menunjukkan grafik hasil uji kekerasan PLA 2002D Murni dan variasi filamen PLA-CNT.

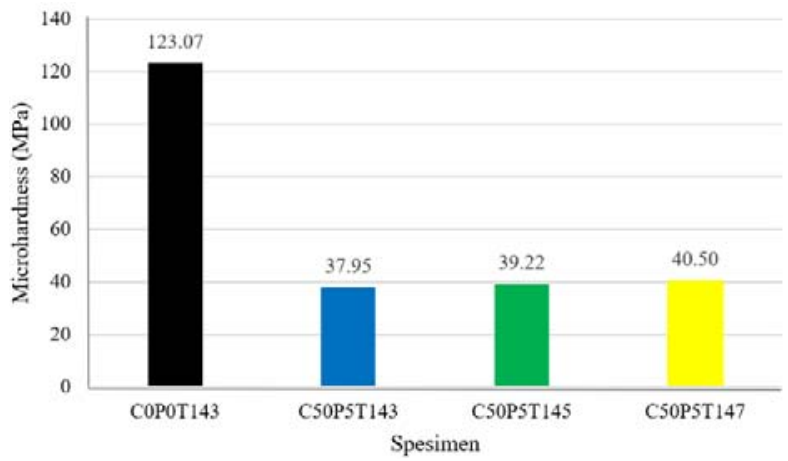

Gambar 6. Hasil Pengujian microhardness PLA 2002D dan Variasi Filamen

Hasil pengujian menunjukkan semua variasi filamen mengalami degradasi nilai kekerasan. Penurunan pada filamen dengan penambahan CNT sebesar 5\% adalah hingga $\pm 75 \%$ pada semua varian temperatur ekstrusi. Pada temperatur ekstrusi $143^{\circ} \mathrm{C}$ mengalami penurunan nilai kekerasan yang paling besar yaitu mencapai 37,95 $\mathrm{MPa}$. Hal ini selaras dengan hasil uji DSC dan FTIR, dimana sifat mekanis pada varian PLA-CNT mengalami penurunan. Peran dari PEG sebagai plasticizer mempengaruhi dari hasil sifat mekanis campuran filamen, dimana PEG telah mengurangi kekakuan dan kekuatan [15]. Selain itu, adanya porositas juga 
mempengaruhi dari hasil microhardness dari komposit filamen. Kekerasan tertinggi dari campuran PLA-CNT dimiliki oleh varian dengan temperatur ekstrusi $147^{\circ} \mathrm{C}$ dengan nilai kekerasan sebesar 40,50 MPa. Nilai ini masih jauh untuk keperluan pembuatan jaringan biomedis, sebagai contoh jaringan tulang tengkorak lakilaki yang memerlukan nilai sebesar 14,7 HV atau sama dengan $\pm 140 \mathrm{MPa}[16]$.

\section{PENUTUP \\ Kesimpulan}

Proses pembuatan filamen PLA-CNT dengan penambahan zat tambahan PEG telah berhasil dilakukan pada penelitian ini. Hasil morfologi permukaan filamen memperlihatkan bahwa proses ekstrusi pembuatan filamen berjalan dengan feeding dan pressure yang tidak stabil, serta adanya porositas yang menurunkan sifat mekanis dari filamen. Semua variasi filamen memiliki derajat kristalinitas sedikit lebih tinggi daripada PLA 2002D Murni, tetapi mengalami penurunan kembali setelah melewati glass transition temperature $\left(\mathrm{T}_{\mathrm{g}}\right)$. Filamen juga mengalami perubahan komposisi kimia yang signifikan, dimana hal itu menurunkan kekuatan ikatan antar senyawa pada material penyusun filamen. Hal tersebut didukung oleh menurunnya sifat mekanis dari filamen, dimana memiliki nilai kekerasan lebih rendah hingga 75\% daripada PLA Murni 2002D. Sehingga dapat disimpulkan penambahan CNT dan PEG pada PLA 2002D menjadikan PLA mempunyai sifat yang getas.

\section{DAFTAR PUSTAKA}

[1] Shahrubudin, N., Lee, T.C. and Ramlan, R., 2019, "An overview on 3D printing technology: Technological, materials, and applications", Procedia Manufacturing, 35, pp. 1286-1296. doi: 10.1016/j.promfg.2019.06.089.

[2] Wang, L., Qiu, J., Sakai, E. and Wei, X., 2016, "The relationship between microstructure and mechanical properties of carbon nanotubes/polylactic acid nanocomposites prepared by twin-screw extrusion", Composites Part A: Applied Science and Manufacturing, https://doi.org/10.1016/ j.compositesa.2015.12.016.

[3] Solechan, S.R., 2016, "Karakteristik filamen biodegradasi print $3 \mathrm{~d}$ untuk implan plate an sekrup tulang femur dengan metode screw extrusion dari material pcl, pla pati ketela dan hydroxyapatite bovine", Prosiding SNATIF 3.

[4] Liu, W., Wu, N. and Pochiraju, K., 2018, "Shape recovery characteristics of $\mathrm{SiC} / \mathrm{C} / \mathrm{PLA}$ composite filaments and 3D printed parts", Composites Part A: Applied Science and Manufacturing 108 (February), pp. 1-11, doi: 10.1016/j.compositesa.2018.02.017.

[5] Arifvianto, B., Leeflang, M.A. and Zhou, J., 2017, "Diametral compression behavior of biomedical titanium scaffolds with open, interconnected pores prepared with the space holder method", Journal of the Mechanical Behavior of Biomedical Materials, 68 (December 2016), pp. 144-154, https://doi.org/ 10.1016/j.jmbbm.2017.01.046.
[6] Zhou, Y., Lei, L., Yang, B., Li, J. and Ren, J., 2018, "Preparation and characterization of polylactic acid (PLA) carbon nanotube nanocomposites", Polymer Testing, j.polymertesting.2018.03.044.

[7] Balani, K., Verma, V., Agarwal, A. and Narayan, R., 2015, BIOSURFACES: A Materials Science and Engineering Perspective, John Wiley \& Sons, Inc., Hoboken, New Jersey.

[8] Hoidy, W.H., Ahmad, M.B., Al-Mulla, E.A.J. and Ibrahim, N.A., 2010, "Preparation and Characterization of Polylactic Acid/Polycaprolactone Clay Nanocomposites", Journal of Applied Sciences 10, pp. 97-106, doi: 10.3923/jas.2010.97.106.

[9] Eliyana, A. and Winata, T., 2017, "Karakterisasi FTIR pada Studi Awal Penumbuhan CNT dengan Prekursor Nanokatalis Ag dengan Metode HWCVHF-PECVD", Jurnal Fisika Dan Aplikasinya 13(2), p.39, https://doi.org/10.12962/ j24604682.v13i2.2155.

[10] Asadi, H., Rostamizadeh, K., Salari, D. and Hamidi, M., 2011, "Preparation of biodegradable nanoparticles of tri-block PLA-PEG-PLA copolymer and determination of factors controlling the particle size using artificial neural network", Journal of Microencapsulation 28(5), pp. 406-416, https://doi.org/10.3109/02652048.2011.576784.

[11] Li, W., Li, R., Li, C., Chen, Z.-R., and Zhang, L., 2015, "Mechanical Properties of Surface-Modified Ultra-High Molecular Weight Polyethylene Fiber Reinforced Natural Rubber Composites", Polymer Composites, https://doi.org/10.1002/pc.23685.

[12] Yuniarto, K., Purwanto, Y.A., Purwanto, S., Welt, B.A., Purwadaria, H.K., and Sunarti, T.C., 2016, "Infrared and Raman studies on polylactide acid and polyethylene glycol-400 blend", AIP Conference Proceedings 1725, https://doi.org/10.1063/ 1.4945555.

[13] Calleja F.J.B., 1985, "Microhardness relating to crystalline polymers", Adv Polym Sci., https://doi.org/10.1007/3-540-13779 -3_19.

[14] de Carvalho, J.G., Zanini, N.C., Claro, A.M., do Amaral, N.C., Barud, H.S. and Mulinari, D.R., 2021, "Composite filaments OF PHBV reinforced with $\mathrm{ZrO} 2 \cdot \mathrm{nH} 2 \mathrm{O}$ particles for 3D printing", Polymer Bulletin, https://doi.org/10.1007/s00289021-03610-3

[15] Bijarimi, M., Ahmad, S., Rasid, R., Khushairi, M.A. and Zakir, M., 2016, "Poly(lactic acid)/Poly(ethylene glycol) blends: Mechanical, thermal and morphological properties", AIP Conference Proceedings 1727 (April 2016), https://doi.org/10.1063/1.4945957.

[16] Ramrakhiani, M., Pal, D., Murty, T.S., 1979, "Micro-identation hardness studies on human bones", Cell Tissues Organs 103, pp. 358-362. 